\title{
Library jobs and student retention
}

\author{
By Stanley Wilder
}

Administrative Services

Louisiana State University Library

\section{The library can contribute to the university's goal of retaining students and enhance its own mission at the same time.}

oncern over the role of the student worker in the academic library has traditionally focused on a set of narrowly defined objectives, usually related to topics such as productivity, turnover, and absenteeism. This is natural in an environment which is so dependent on students to perform such vital functions in its day-to-day operations.

The role of the student worker in the academic library, however, can be considered from a wider perspective, one that includes the contribution that library employment makes to the university's larger concerns. In particular, there is evidence that parttime, on-campus jobs tend to increase retention rates among both white and minority students. Library administrators need to be aware of this additional benefit that their student jobs provide the university and should consider the possibility of adopting a more proactive approach to encouraging retention. Such an approach could benefit the library and the university.

\section{Background}

Retention, also called persistence, is the rate at which new students at an institution go on to complete their programs there. Given that staying in school is not in the best interest or even the objective for all students, why does the university place such emphasis on it?

On one level, increasing retention is simply an economic concern for the university. As Noel explains, universities face declining enrollments, which leads to losses of revenue. This trend is due in part to declining birth rates, a decline in the college-going rate for 18-19-year-old males, and a continued level of high attrition (dropout) dating from the mid 1970s.

In addition, retention has recently become important as an "educational outcome" measure. American universities are now under continuous pressure from state legislatures, accrediting bodies, and the private sector to demonstrate that increased, or even maintained, funding produces a corresponding increase in the quality of services. Retention rates are one relatively firm measure of

${ }^{1}$ Lee Noel, "Increasing Student Retention: New Challenges and Potential," in Lee Noel, Randi Levitz, Diana Saluri and Associates ed., Increasing Student Retention: Effective Programs and Practices for Reducing the Dropout Rate (San Francisco: Jossey-Bass, 1985), 4-7. 
the degree to which the university satisfies the needs of its students.

Perhaps the most pressing problem leading university administrators to pay close attention to retention, however, is minority enrollment, and black enrollment in particular. Blacks stay in school at a significantly lower rate than do whites, leading university administrators concerned with minority representation to pay as much attention to retention as to recruitment. ${ }^{2}$

\section{Which students are at risk?}

It is not possible to create a precise profile of students "at risk" to drop out, but the literature consistently identifies several broad groups of students with high attrition rates: ${ }^{3}$

\section{Minority students}

2. Low-income students

3. First generation students

4. Academically unprepared students

5 . Students with uncertain goals

6. Students with full-time jobs

7. Commuting students

Nearly every retention study points out that while many college dropouts cite financial considerations among their reasons for leaving school, lack of money cannot be considered as a base cause for dropping out. " "Low-income students" are cited above, for example, primarily because they tend to receive inadequate training in primary and secondary schools. ${ }^{5}$

\section{The role of the part-time, on-campus job}

While there is no research examining the connection between retention and part-time library jobs in particular, a solid body of work supports the proposition that jobs such as these do promote retention. ${ }^{6}$ The leading study in the area was con-

${ }^{2}$ Alexander W. Astin, Preventing Students from Dropping Out (San Francisco: Jossey-Bass, 1975).

${ }^{3}$ Louise Lonabocker, "Can an Institution Construct a Dropout Profile?" College and University 58 (Fall 1982): 76.

${ }^{4}$ Vincent Tinto, "Dropout from Higher Education: A Theoretical Synthesis of Recent Research," Review of Educational Research 45 (1975): 89-125.

${ }^{5}$ Leonard A. Valverde, "Low-Income Students," in Increasing Student Retention, 78-94.

${ }^{6}$ For other studies linking part-time, on-campus employment to higher retention, see Tullisse A. Murdock, "The Effect of Financial Aid on Student Persistence," paper given at the Association for the Study of Higher Education Annual Meeting, San Diego, February, 1987; Richard Voorhees, "Finan- ducted by Alexander Astin, who reports: "Having a job usually increases the student's chances of finishing college. If employment is less than full-time (under twenty-five hours a week), the absolute benefits can be substantial: from 10 to $15 \%$ decrease in dropout probabilities. These positive effects of employment are even more pronounced among black students." ${ }^{\prime 7}$ Astin goes on to discount the type of work as a factor in increasing retention: "Both work in an academic-related department and work in a non-academic part of the campus have similar positive effects for men and women and for blacks and whites." 8 A recent study by the National Center for Education Statistics reports positive results even for students having trouble in school: "employment displayed a large, positive effect on persistence for low ability students. For example, $80 \%$ of students in public 4-year institutions who did not work persisted. $98 \%$ of students who worked during the academic year persisted." 9

\section{The role of involvement}

No one suggests that there is anything intrinsic to answering phones or reshelving books that encourages students to stay in school. There is, however, another body of research which may point to the source of the connection between on-campus, part-time jobs and retention. A major theme of the retention literature is that students who avail themselves of the means to become socialized to their new academic environment are more likely to persist in school. ${ }^{10}$ According to this model, any

cial Aid and Student Persistence: Do Federal Campus-Based Aid Programs Make a Difference?" Journal of Student Financial Aid 15 (Winter 1985): 21-30; Dawn Terkla, "Does Financial Aid Enhance Undergraduate Persistence?" Journal of Student Financial Aid 15 (Fall 1985): 11-18.

${ }^{7}$ Astin, 5 .

${ }^{8}$ Astin, 7.

${ }^{9}$ C.Dennis Carroll, College Students Who Work: 1980-1984 Analysis Findings from High School and Beyond (Washington, D.C.: National Center for Educational Statistics, 1988), 71-78.

${ }^{10}$ For research supporting the connection between on-campus activities and retention, see Astin, 89-145; J.M. Billson and M.B. Terry, "In Search of the Silken Purse: Factors in Attrition Among First Generation Students," College and University 58 (Fall 1982): 57-75; L. Ramist, "College Student Attrition and Retention," College Board Report No. 81-1, (New York: College Entrance Examination Board, 1981); W.D. Churchill and S.I. Iwai, "College Attrition, Student Use of Campus Facilities, and a Consideration of SelfReported Personal Problems," Research in Higher Education 14 (1981): 353-365. 


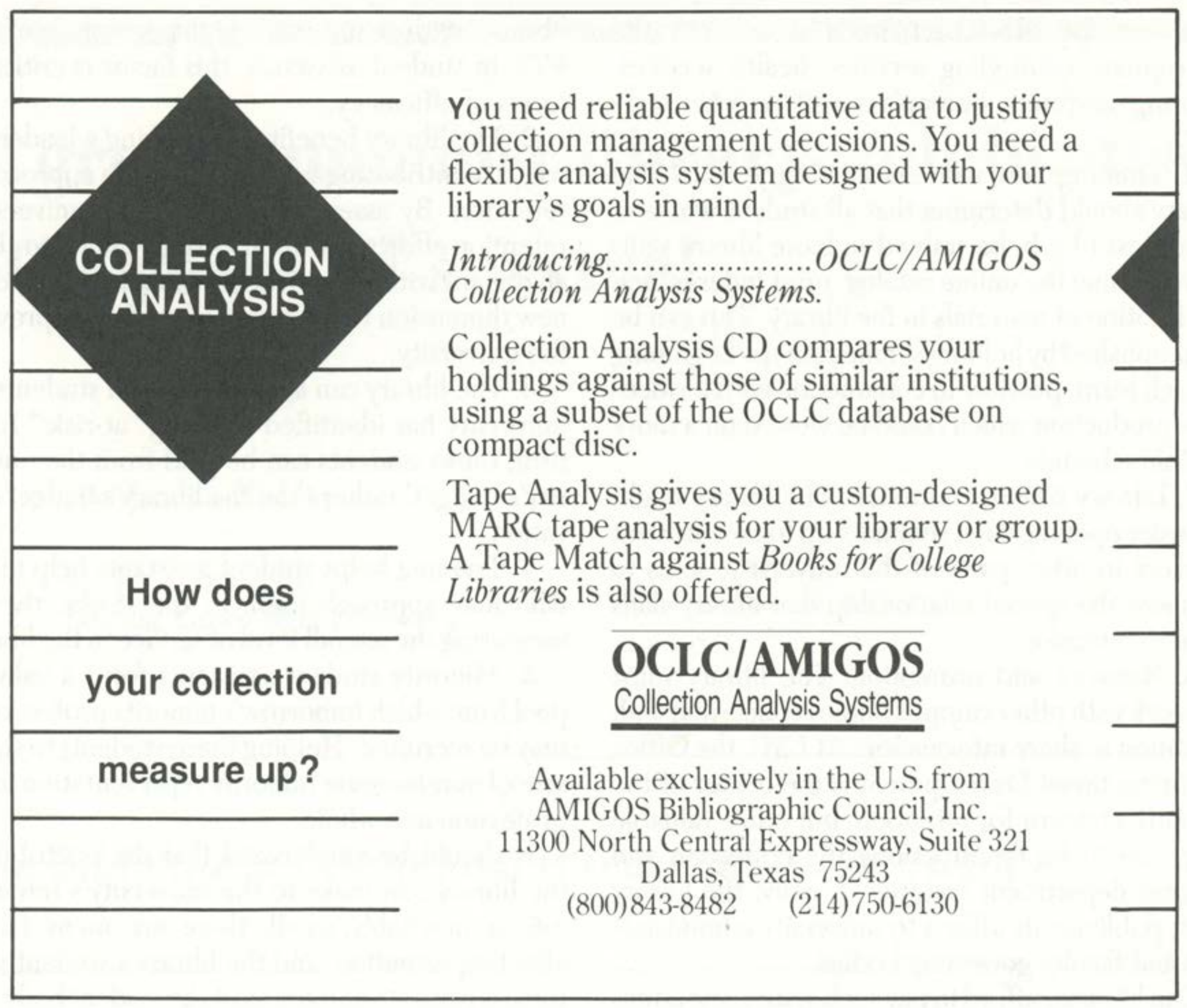

campus mechanism which tends to bring about a good "fit" between student and institution will improve retention rates.

This research, taken together with the part-time employment research noted above, suggests that jobs in the academic library may help increase retention to the extent that they socialize students to the university, and provide them with schoolrelated support networks of fellow students and staff members.

\section{Natural advantages of the library job}

It should be clear to any academic librarian, however, that where on-campus jobs are concerned, the part-time library job has the potential to encourage retention in ways that other on-campus jobs cannot. Without any conscious effort on the part of librarians, library student workers already benefit from certain "natural" academic advantages:

1. Library jobs demystify the library. For students who would otherwise feel intimidated by the library, daily contact reduces anxiety and may produce a positive predisposition to further use.

2. There may be a benefit to physically placing at-risk students in a study-related environment, in close contact with good academic role models.

3. Library work naturally exposes students to materials which can be useful in completing course work.

\section{The program at LSU}

The LSU Library is preparing a proactive approach to the retention of its student workers which is intended to exploit the natural advantages noted above. The following are the key elements of that program:

1. Data collection. No library will be able to make a case for unusually high retention among its student workers without supporting data. LSU is able to track the retention of its student workers by asking the university's Budget and Planning Office to run its student payroll computer tapes against its registration tapes. Students selected in this way are run through the university's retention tracking computer programs to insure comparability with university figures.

2. Retention awareness in new supervisor training. Supervisors must be made aware of retention as an issue in student supervision, and how the supervisor and library can work together to encourage it.

3. Collection of up-to-date referral information. In many cases, the first person to recognize that a student is experiencing some kind of trouble will be his or her supervisor. With the aid of a handbook, a 
supervisor should be able to refer the student to the appropriate counseling services, health services, tutoring programs, women's transit, or other services.

4. Training new workers in library skills. The library should determine that all student workers, regardless of job, be trained in basic library skills such as using the online catalog, print indexes, and the location of materials in the library. This can be accomplished by holding seminars at the beginning of each term, possibly in conjunction with a videotape production which could be viewed on a more flexible schedule.

5. Library training outreach. The library might consider opening such seminars up to new student workers in other parts of the university, so as to promote the special relationship that library skills have to retention.

6. Network and promotion. The library must network with other campus bodies concerned with retention to share information. At LSU, the Office of Instructional Development is the center of the campus' concern for retention, but other valuable allies are to be found among the education and English department faculties. Finally, the library must publicize its efforts to university administrators and faculty governing bodies.

Can libraries afford to pay such systematic attention to an issue which lies outside their immediate domain? In fact, a successful program could pay off in very concrete terms:

1. Higher retention of students should mean lower turnover of student workers. This will lead to lower training costs and higher productivity. For libraries with an unusually high percentage of total FTE in student assistants, this factor is critical in terms of efficiency.

2. The library benefits from taking a leadership role in contributing to a campus-wide approach to retention. By asserting itself into the university's retention efforts, the library brings itself into closer alignment with the university's mission, and adds a new dimension to the range of services it provides the university.

3. The library can agree to take on students the university has identified as being "at-risk." In return, these students can be paid from the university's budget, rather than the library's budget allocation.

4. Training helps student assistants help others who may approach them in the stacks, thereby increasing the overall level of service in the library.

5. Minority student assistants form a valuable pool from which tomorrow's minority professionals may be recruited. Helping these students to stay in school may increase minority representation in the profession as a whole.

It should be emphasized that the contribution the library can make to the university's retention rate is inevitably small; there are many factors affecting retention, and the library's student work force is just a small fraction of the student body. But the very diversity of factors affecting retention underscores the need for a campus-wide approach to the problem, and increases the relative importance of each piece of the solution. The challenge for the academic library is to recognize its own contribution to that solution and to act on it.

\section{University librarians attend Nordic seminar}

Eleven North American librarians and archivists attended a seminar in Oslo September 3-9 that was organized by Riksbibliotektjenesten, Norway's national office for research and special libraries.

The seminar had five objectives: to promote cooperation and exchange of information among Nordic, American, and Canadian librarians, archivists, and information specialists; to improve the quality of information on Nordic countries available in Canada and the United States; to provide participants with information regarding the most recent Nordic reference sources; to improve communication between North American academic libraries and the publishers and book trade representatives of Nordic countries; and to improve bibliographic access by exploring possible cooperative efforts in such areas as library computer networking, electronic indexing of periodical literature, and specialized bibliographies.

The eleven North Americans attended as repre- sentatives of important Nordic collections: University of Alberta, Augustana College (Swenson Swedish Immigration Research Center), UCLA, University of Chicago, the Library of Congress, University of Manitoba, McGill University, University of Minnesota, Pacific Lutheran University, and University of Washington. They heard leading specialists from Norway, Denmark, Sweden, Finland, and Iceland in the fields of bibliography, automation, publishing, manuscripts, and government publications and information services.

\section{SPIPCIIAIL COLLLECIIONS}

